Scientia Militaria vol 40, no 3, 2012, pp.71-108. doi: 10.5787/40-3-1040

\title{
All splendid, but horrible: The Politics of South Africa's Second "Little Bit" and the War on the Western Front, 1915-1918
}

\author{
Ian van der Waag ${ }^{\bullet}$
}

\begin{abstract}
South Africa's decision to enter the First World War was not easy. After a difficult interplay between Whitehall and Tuinhuis, the Botha government agreed to secure limited strategic objectives in neighbouring German South West Africa. An armed insurrection had to be suppressed first. When both these objects were achieved, and following a further British appeal, South African troops moved further afield. This move, representing South Africa's second 'little bit', was a dangerous step for the Botha government. The despatch of troops to France was controversial. Yet, by the end of 1915, South African expeditionary forces were en route to Europe and East Africa. This paper investigates the political crisis in South Africa and the difficult decision to send troops out of Africa, their deployment in an environment entirely foreign to the South African way of war, and the impact of the Western Front on the drawing of 'lessons' by post-war Union authorities.

Keywords: First World War, South Africa, France, defence policy, Union Defence Force, UDF

\footnotetext{
Ian van der Waag, MA (Pretoria), PhD (Cape Town), is an Associate Professor in the Department of Military History, Stellenbosch University, South Africa. This article is a re-visitation of a paper presented at The Somme: 90 Years On conference, hosted by the School of History, University of Kent, and the Defence Studies Department, King's College, London, in Canterbury, 17-19 July 2006. Assistance received from the National Research Foundation's Rated Researchers Incentive Programme, which allowed further research prior to publication here, is gratefully acknowledged.
} 


\section{Introduction: 'Our Thermopylae, our Morgarten'}

The title for this paper draws on two sources; one a letter from William Carter, the Archbishop of Cape Town, and the other a 21 July 1915 newspaper call for volunteers to serve in France with a South African infantry brigade. For the Union of South Africa, which had a fortnight earlier brought the German South West campaign to a successful conclusion, this would be the country's 'second little bit'. ${ }^{1}$ The stance of the South African prelate, captured in his wartime correspondence with a cleric friend in Britain, was typical of other English-South Africans at the time. After succumbing easily to the wave of early-war enthusiasm, he had settled by mid-1915 into a new realism. ${ }^{2}$ The accounts of the fighting in Europe were terrible and, as he admitted, he did not understand how men could stand the brutality of it all. Yet, while he saw too that there were most probably 'worse things to come', he embraced the notion that the war was being fought for civilisation and justice and for these reasons, despite the horribleness, it was also 'all splendid. ${ }^{3}$

Soldiers at the front, situated at the tactical level and subjected to the full experience of the trenches, shared other ideas. Lt Cyril NewtonThompson, a perceptive South African with the Royal Horse Artillery in France, derided the generals, the politicians, a gullible public, in fact everything about the war. Any gains would be more than offset by the losses, which, he lamented, would be appalling,

'The soldiers will have gone to their last long rest recking [sic] little of why it all was, except that they thought our cause the better, \& it will be left to the historian \& especially the student of military history to determine whether in the great offensive of June-July-August 1916 the game was worth the candle.' ${ }^{4}$

As Newton-Thompson predicted, this question has drawn its historians and other commentators. For South Africa, the focus has always been, most specifically, Delville Wood. This tradition commenced on 18 July 1917, when a large crowd gathered at the Town Hall in Cape Town to mark the first Delville Wood Day. The tribute, offered 'to the memory of the noble band of South Africans who ... made the supreme sacrifice at Delville Wood under circumstances which have won imperishable glory for their country', was, as the Cape Times reported, 'most impressive ... and in every respect ... worthy of the great anniversary that it marked. ${ }^{, 5}$ And it was a 
great anniversary for several reasons. First, although only an episode on the Western Front, it was far more than that to the South Africa of the day. Delville Wood was, according to John X. Merriman, elder statesman and former Cape prime minister, 'the first stiff fight' in which the new Union Defence Force (UDF) 'met under the most extreme conditions of modern warfare' and where they showed 'themselves not unequal to the dreadful task.' The Somme and, more specifically, Delville Wood, was moreover a sacred place where South Africans stood, not only together, but with the rest of the British World, and halted German militarism. And therefore, although 'only an episode in the great strife', it defined not only the grittiness of the South African soldier, but also South Africa's place as a constituent of a larger British World and as part of the allied coalition that halted despotism. It was Merriman felt South Africa's Thermopylae, her Morgarten. ${ }^{6}$

This line has been assumed, both by soldiers and historians, with the result that Delville Wood, South Africa's special part in the Battle of the Somme, looms large in South African military history. Contemporary soldiers played the first part in this construction. Major-General William Furse, commander of the $9^{\text {th }}$ Division, of which the South African Brigade formed part, described the events around Longueval as 'one of the greatest battles in the world's history', while Lieutenant-General Henry Rawlinson, his immediate superior, declared that 'with the capture of Delville Wood, the gallantry, perseverance and determination of the South African Brigade deserves the highest commendation. ${ }^{7}$ Delville Wood, almost inevitably, has been used by politicians and nation-builders of pre-1994 white South Africa and in a book, published in 2006, Delville Wood is, yet again, billed as one of the 'seven battles that shaped South Africa." ${ }^{8}$

These constructions and the complicated nature of the South African deployment on the Western Front, divergent and often unconnected, have slanted the historical record. Several South African units and formations served in France during the Somme offensives. The $1^{\text {st }}$ South African Infantry Brigade formed the core of this presence, but did not fight in the vicinity of the five batteries of heavy artillery or the signal company or, indeed, the South African General Hospital stationed near Abbeville. All were served by the men of the South African Native Labour Corps (SANLC). Besides, there were also South Africans in many British battalions and regiments and in the Flying Corps. Nevertheless, the focus of 
the historian of South Africa's part in the campaign has always been with the Infantry Brigade, which was not only the most visible South African contribution to the main battleground, but, to invoke Buchan, claimed 'to have had no superior and not many equals. ${ }^{, 9}$ More recently, these studies, often simply chronicling events, have been supplemented by studies of the activities of the SANLC, which arrived in France in late 1916, too late for the battle of the Somme. ${ }^{10}$ During the past decade, much new work has been done exploring both 'identity' as well as the meaning of the battle to a modern, collective, new South Africanism. ${ }^{11}$

The aim of this paper, which draws on an array of official and private papers, is to investigate the South African experience of the battle of the Somme, cast against the background of the political crisis in South Africa and the difficult decision to send troops out of Africa and the deployment of these troops in an environment entirely foreign to the South African way of war. A small assemblage of South Africans, all second, third and lower-tier figures, are used as lenses through which to view these processes. They include William Carter (1850-1941), the archbishop of Cape Town; Hugh Wyndham (1877-1963), the shadow defence minister, and his wife, Maud (1880-1952); Captain H.W.M. Bamford, of the $1^{\text {st }}$ SA Infantry Brigade; Lt Cyril Newton-Thompson, a young South African serving in the British Army; Captain William Lennox-Gordon, a medical officer with the South African General Hospital at Abbeville; and Sergeant-Major Alex Knox of the $1^{\text {st }}$ South African Field Ambulance.

\section{The politics of participation: a 'second little bit'}

South Africa's decision to enter the First World War and assist Britain in the struggle was not easy. Despite the propaganda regarding the Unification of South Africa (1910) and the supposed confluence of the 'white' sectors English and Afrikaans - into a new South Africanism, South Africa was not a united country in 1914. There was no South African nation, no consensus on the war. Even the nomenclature differed. For English South Africans, following the British trend, it was the Great War. ${ }^{12}$ For the clerks in the South African defence department it was 'the European Crisis'; for their counterparts in the prime minister's office in 1914, it was 'the German South West Expedition', almost as if these two events could be separated. ${ }^{13}$ For F.S. Malan, the education minister, it was, in August 1914, 'die Brits- 
Duitse-oorlog' (the Anglo-German War), ${ }^{14}$ a description supported by M.T. Steyn, the former Orange Free State president, who, writing to Smuts on 31 July 1914, reckoned that 'the troubles in England are the result of the South African War. One sees still more. This war has driven England out of her "splendid isolation" into her "ententes" and her yellow alliances and today she has fallen foul of Continental entanglements. The mills of Providence grind slowly indeed! ${ }^{15}$ The Republican Boers had hoped for this in 1900. Now, fourteen years later, this happened and there was, to the mind of the Afrikaner nationalist, no reason whatever to help Britain. They might, as Steyn was suggesting, rather seize the moment offered by Providence.

\begin{tabular}{l|ccc|ccc}
\hline & \multicolumn{3}{|c|}{$\mathbf{1 9 1 0}$} & & \multicolumn{3}{c}{1915} & \\
\hline Party & Seats & Votes & Percent & Seats & Vvotes & Percent \\
Labour & 3 & 11549 & 10.9 & 4 & 25690 & 9.8 \\
Labour - GM & & & & - & 802 & 0.3 \\
Independent & 12 & 19563 & 18.5 & 5 & 10911 & 4.2 \\
Independent Lab & 1 & 815 & 0.8 & & & \\
Independent SAP & 1 & 3430 & 3.2 & & & \\
Independent UP & 2 & - & & & & \\
National Party & & & & 27 & 78184 & 29.9 \\
SAP & 66 & 30052 & 28.4 & 54 & 93482 & 35.8 \\
Socialist & - & 448 & 0.4 & & & \\
Unionist & 36 & 39766 & 37.6 & 40 & 48034 & 18.4 \\
\hline
\end{tabular}

Table 1: The position of parties in South Africa, The House of Assembly, 1910 and 1915.

- The Independent Unionists were uncontested in two seats in the Cape Province. (Source: B.M. Schoeman, Parlementêre verkiesings in Suid-Afrika, 33, 66-67.)

Unsurprisingly therefore, Louis Botha, former Boer general and now wartime prime minister, battled to achieve and then maintain consensus in his cabinet. Faced with potential defections and the growing rift in Afrikanerdom, his first wartime ministry was unstable and his second ministry, formed after the October 1915 election, could only govern with Unionist support, though not in formal coalition (table 1). Nationally, Botha found himself between two camps: a 'British' sector, wanting to involve South Africa fully in the war, and an Afrikaner camp, wanting South Africa to remain neutral. The first considered it South Africa's duty, as a loyal dominion of the empire, to freely support the British war effort. In fact, during the 1912 defence debate, the Unionists had predicted a time when 
South Africa would not only have to assume responsibility for her own defence, but also offer the 'old country' the support of a South African expeditionary force. ${ }^{16}$ To Afrikaner nationalists this was anathema. Botha, perhaps naively, had hoped to unite the country behind the war effort, and so smear longer term bonds. This was, as Frans Malan noted, 'wonderful politics' and Botha succeeded to a surprising degree in quietening the voice of radical labour and nationalistic Africans. However, as Malan predicted, Botha, by committing South Africa to the war, would run 'the danger of losing the sentiment of the [Afrikaner] people. ${ }^{, 17}$ The war and the questions it opened fuelled Afrikaner nationalism.

Furthermore, South Africa's military task was complicated. The Union Defence Force was little more than two years old and South Africa, as Buchan reminds us, had 'foes within and without her gates. ${ }^{18}$ Her task, 'of all the nations of the British Commonwealth ... [was] at the outbreak of war the most intricate. ${ }^{19}$ Nonetheless, at the beginning of August 1914, South Africa duly offered to take care of her own defence, so freeing imperial troops for deployment to France. The defences of South Africa were now for the first time manned solely by the new UDF, some of whom, disliking the tedium of garrison duties and the manning of home defences, were anxious to form a South Africa expeditionary force. Failing this some left to join the British Army. ${ }^{20}$

Just as the UDF was being organised for homeland defence, the monitoring of the Germans across the Orange and the maintenance of a strike force in the event of an African rising or industrial unrest, Britain asked South Africa to capture the wireless stations in neighbouring German South West Africa. After considerable deliberation in a divided cabinet, South Africa acquiesced on August $10 .^{21}$ Although appreciating South Africa's political and military difficulties, London pushed Pretoria toward an early expedition. ${ }^{22}$ However, broad-based public opinion stood in sharp contrast to the parliamentary division approving the war plans. Botha and Smuts, egged on by the English-speaking community, embraced the comfortable notion that their Afrikaner compatriots welcomed the opportunities for nation building and patriotism presented by the war with equal enthusiasm. ${ }^{23}$ Hugh Wyndham, a prominent Unionist and shadow defence minister, misreading the situation entirely, reported that 'the feeling amongst the Boers out here is excellent ${ }^{24}$; while his wife, a Lyttelton, was 
sure that 'the feeling can never go back to what it was before that's certain. ${ }^{25}$ Yet, far from nation-building and created some common 'feeling', the war presented for what Bill Nasson has termed 'the nonloyalist strata of Afrikaner society' unique opportunities for partypoliticking and their far-right hoped to seize the chance to restore a Boer republic. ${ }^{26}$

Nonetheless, despite the Afrikaner Rebellion, sparked by the South African invasion of neighbouring German South West Africa, and increasing bitterness through 1915, Botha, refusing to accept a final break between himself and the Afrikaner far-right, continued to hope for rapprochement. This was made difficult by the Unionists, who, although the official opposition, were committed to an active war policy. Botha's position was made more complicated by the general election that October, although unwisely he did not to keep the brigade in South Africa for the election. He could ill-afford to lose their votes. ${ }^{27}$ The Free State voted solidly for Hertzog and, still worse, what the English sector branded 'Hertzogism' had spread to the other provinces and particularly to the Transvaal and the Cape, where Dr D.F. Malan led the nationalists and edited their Cape newspaper, De Burger. The electoral result, a severe disappointment to Botha, was such that he, most reluctantly, could only remain in office with the parliamentary support of the Unionists. Divisions were worse than ever. Moreover, the Unionists, although giving Botha a majority in the house, felt excluded from real government. They were drawn, in some degree, into wartime decision support and even military office, but there was no war government or government of national unity. Furthermore, the Nationalists would have no part in the war effort and on this matter they were joined at times by what remained of the Labour Party. Botha, like the official opposition, believed that good war news would solidify the country, undermine the belief in nationalist quarters that Britain was going to be defeated, and so build a larger measure of national unity. Wyndham noted that the Afrikaner, recognising potential post-war rewards, had 'a healthy desire to be on the winning side. ${ }^{28}$

However, the Union Defence Force, the instrument that was to manufacture this loyalty to empire, was, like the Union of South Africa, a compromise between the determination of English-speakers to maintain the 'British connection' and the desire of Afrikaner nationalists for a restoration 
of Boer political and military traditions. Barely two years old and notwithstanding the initial blunders and mistakes, the UDF, thanks in no small measure to the ability and determination of Smuts, captured German South West Africa. ${ }^{29}$

\section{Raising and despatch of an infantry brigade}

The Germans surrendered the territory unconditionally on 9 July 1915 and during October, with the election over and his political position stabilised, Botha, urged on by the Unionists and 'loyal' Afrikaners, turned to the war once more. The pro-war elements were concerned that South Africa was not doing enough; Maud Wyndham, representative of this opinion, complained to her mother-in-law, that life in South Africa was 'smug \& comfortable almost as if there was no war. ${ }^{30}$ South Africa exported steel and war-related materials to Britain, Russia, France, Italy and Japan, but Botha, aware that South Africa's economic wellbeing was tied to the fortunes of the British Empire, felt obliged to do more than simply support the wider British war effort through South African trade and industry. ${ }^{31}$

A new realism was now dawning. For the British sector, the early-war enthusiasm, experienced by many Afrikaners as ultra jingoistic, had gone; while many Afrikaners, of the disloyal type, came to accept that the war would not provide opportunity to address old grudges with Britain. Moreover, many South Africans, men like Newton-Thompson, having left to join the British armed forces, were already serving on the Western Front and there had been some talk of recruiting of men in South Africa for enlistment in the New Army. ${ }^{32}$

At the end of June 1915, before the conclusion of the German South West campaign, Britain approached South Africa on the question of a South African expeditionary force for France. John Buchan, succumbing to South African nation-building and the sensing the need to boost the image of Botha and Smuts after 1918, credits them for initiating the proposal. ${ }^{33}$ But this immediately encountered difficulty, as South Africa was not prepared to discuss 'the contingent question' until the campaign in German South West Africa (GSWA) had been concluded. Moreover, with an impending election, it was inadvisable to call parliament. ${ }^{34}$ Going to parliament, before the conclusion of the campaign in German South West, to vote the money for a 
campaign somewhere else, would raise 'acute political controversies ... with results which [Smuts forecast] might be most undesirable. ${ }^{, 35}$ Lord Buxton, the governor-general, agreed and so Britain left the question. But, on 9 July 1915, on the day of the surrender, Buxton was pushing his ministers again; 'now', he wrote to Smuts, 'that this affair [in GSWA] is over I suppose South Africa will break out in a new place - I wonder where? ${ }^{36}$

These questions - whether another expeditionary force would be raised and where it would serve - elicited mixed feelings. Merriman, for one, felt that South Africa had already made its great sacrifice, both in terms of money and the GSWA campaign. ${ }^{37}$ Moreover, this campaign had been fought to ensure the security of her own borders. The theatres now proposed for South African involvement - East Africa and France - were geographically distant and, creating further ambiguity, the South Africa Defence Act (No 13 of 1912) authorised only a deployment of the UDF in 'South Africa' and for the immediate defence of the Union. For this reason, volunteers could only be deployed further afield. However, from September 1914, many South Africans had left for Europe to enlist as individuals in the British Army and, following Franke's surrender, more were expected to leave. It seemed a pity that these men, willing to serve in Europe, were not fighting as South Africans. Moreover, as Graaff acknowledged, the government was under increasing pressure and they would have to do something 'to meet the demands of those who are anxious to see a contingent depart.' In fact, Pretoria, recognising that the conclusion of the South West campaign would produce a large number of unemployed men, was quite happy 'to have [these men] at the front than on our hands. ${ }^{, 38}$ For these reasons, the cabinet decided to send another contingent. But where was this 'second little bit' to be sent?

Two theatres were proposed. The first was the main battleground in France, where the other dominions were already well-represented. The other was East Africa. The latter, supposedly 'more in our line' than a European campaign, was supported by a wide number of Britons and South Africans. A small contingent in France would not only be 'swallowed up in the enormous armies' and lose their identity, but, as Graaff noted to Smuts, South Africans had neither the training nor the campaign experience to fit them for the Western Front; whereas in Tanganyika, South Africa would have her own 'show' once again and South African troops 'could fight in 
their own way. ${ }^{39}$ Smuts liked the idea of Tanganyika too. He agreed with the military arguments, the promise of mobility, South Africa's strong suite, in which mounted infantry could play a role, but recognised also that, if South Africa conquered the territory, some sort of exchange with Mozambique might consolidate territories south of the Zambezi and Kunene rivers. ${ }^{40}$

However, Britain had requested specifically an infantry contingent and for the Somme theatre of operations and, when Pretoria responded to London's call, they expressed their 'readiness to render all the assistance in their power in prosecuting the war in Europe and elsewhere. ${ }^{41}$ In doing so, Pretoria hoped to satisfy the British request as well as their own subimperial goals. In pursuance of this dual policy, Pretoria agreed to send a contingent to Europe, which would be composed of the volunteers they expected in large numbers, perhaps sufficient to form a second and even a third brigade. ${ }^{42}$ In fact, with the campaign in GSWA at end, Smuts was confident that South Africa would be able to raise three infantry brigades and then they might even consider forming a South African division. ${ }^{43}$

However, Smuts was to be disappointed. The recruitment drive opened on 21 July 1915, in time to draw the troops returning victorious from German South West. ${ }^{44}$ A call was made both for heavy artillery as well as infantry, ${ }^{45}$ although the War Office had asked specifically for infantry. As expected, there was a flurry of interest, particularly from inhabitants of British blood. ${ }^{46}$ Men rushed again to the colours. Some, like Louis Matthews, writing once the brigade had been formed, was 'afraid of being left in the cold. ${ }^{47}$ However, in view of the small white population and the complexity of South Africa's other tasks, including the pending deployment to Tanganyika, it was agreed that South Africa could not raise and maintain in France much more than a brigade. Buchan has suggested that Botha, not wanting to 'denude the country of too many of her most loyal and vigilant citizens', could in fact send no more than a brigade of infantry to Europe. ${ }^{48}$ On August 10, 1915, Botha informed Buxton that the South African contingent would comprise one infantry brigade, one signalling company, one field ambulance and one general hospital, in addition to five batteries of heavy artillery and some, if not the whole, of the personnel for five four-gun batteries (13-pounder quick-firing) of field artillery and some aviation 
personnel, together with aeroplanes and accessories. ${ }^{49}$ Botha, however, noted rather ominously that reinforcement 'may prove difficult., 50

The force was established in accordance with the war establishments fixed for the New Armies ${ }^{51}$ and the British government assumed liability for pay - an issue soon to have political consequences. ${ }^{52}$ The four battalions, brigaded as the $1^{\text {st }}$ South African Infantry Brigade, were, as indicated in table 2, 'designed to represent the main divisions of the Union, and recruits were given the option of joining the regiment affiliated to their own province. ${ }^{53}$ This formed part of a difficult, but broad-fronted attempt to gain language equity and balance sectarian interests. As it transpired, the two main military efforts were to be East Africa and France, where Smuts, himself, and Brig Gen H.T. (Tim) Lukin were to command respectively, the former representing the Afrikaans sector, the latter the English. Moreover, with only about 15 percent of the original brigade being Afrikaans, the bulk of the contingent that went to France was English, although by the end of the war, the proportion of Afrikaners had increased to about 30 percent. $^{54}$ Buchan has suggested that Afrikaners, renown as mounted riflemen and having enhanced this reputation in GSWA, were not attracted to Britishstyle infantry and so they were by preference destined for Tanganyika. ${ }^{55}$

\begin{tabular}{l|ll}
\hline Regiment & Source & Commander \\
\hline $1^{\text {st }}$ SA Infantry & Cape Province & $\begin{array}{l}\text { Lt Col F.S. Dawson } \\
\left(4^{\text {th }} \text { SAMR) }\right.\end{array}$ \\
$2^{\text {nd }}$ SA Infantry & $\begin{array}{l}\text { Natal and the Orange } \\
\text { Free State }\end{array}$ & $\begin{array}{l}\text { (District Staff Officer, } \\
\text { Pietermaritzburg) }\end{array}$ \\
& Transvaal and Rhodesia & $\begin{array}{l}\text { Lt Col E.F. Thackeray } \\
\text { (District Staff Officer, }\end{array}$ \\
$3^{\text {rd }}$ SA Infantry & Kimberley) \\
& South African Scottish & $\begin{array}{l}\text { Lt Col F.A. Jones } \\
\text { (District Staff Officer, }\end{array}$ \\
& & Johannesburg) \\
\hline
\end{tabular}

Table 2: The battalions represented the main political divisions in South Africa.

However, in truth, the military experience of those leaving the Union was quite irrelevant to the tasks at hand, both in Tanganyika and France. The 
Union Defence Force, although established in July 1912 and still in embryo when the war broke out, was not inexperienced. But, this experience was all South African, and, almost exclusively of the small-war variety. Moreover, the UDF was a rather difficult marriage of four disparate forces, representing at least three military traditions and speaking two languages. Sectarian interest was very strong and this did not facilitate organisational design and effective command. ${ }^{56}$ And, to complicate matters further, there was little cooperation after August 1914 between the South African defence department and the local British military authorities, something that irritated Major-General C.W. Thompson, the commander of the South African (Imperial) Military Command. Over the following years, relations between the Castle and Defence Headquarters in Pretoria declined, reaching in a nadir in 1917 with the recall of Thompson's successor, Brigadier-General A.E.J. Cavendish. ${ }^{57}$

Members of the public, sensing perhaps the deterioration in local Anglo-South African relations, wondered how the South African commanders, many of them former Boer generals, would perform out of their own country. The campaigns were thought, quite correctly, to be very different to fighting in the Transvaal, which they knew intimately and where their operations had always been defensive. But the former Boer generals were not the sole focus of criticism. Carter, the Anglican prelate, doubted whether the South Africans, as a group, regardless of language, would be a 'match for professional German officers. ${ }^{58}$ Others repeated this view in letters to the press. ${ }^{59}$ Many had little faith in the South African high command. ${ }^{60}$

The $1^{\text {st }}$ South African Infantry Brigade, comprising four infantry battalions, was placed under the command of Brigadier-General Tim Lukin, a seasoned campaigner in South Africa since the time of the Anglo-Zulu War (1879). Both Botha and Smuts had had their doubts about Lukin, which they raised during the GSWA campaign. ${ }^{61}$ They thought him ill-suited to a mobile role and perhaps too wedded to the British way of things. Lacking the necessary African zest, they thought him better suited to warfare in Europe. Moreover, rumours had surfaced that Smuts might be offered command in Tanganyika, in which case a general officer representing the 'English' interest would be good. They could dispatch Lukin to France and, at the same time, satisfy English-South African opinion. Douglas Haig, who encountered Lukin during the Anglo-Boer War, thought him a commander 
of 'great ability' and, in 1918, declared that he viewed him as 'one of the most reliable Divisional Commanders in France. ${ }^{62}$

Of the battalion commanders, only one was South African born (Tanner); but all, like Lukin, had had small war experience. Dawson spent some time as a planter in British Honduras before 1899; while Thackeray, at about the same time, had had an intermezzo as a cowboy in the United States. All saw service in South Africa during the Anglo-Boer War and Dawson, born in Sussex, and Thackeray, in Middlesex, entered the South African structures through the South African Constabulary. All saw service in German South West Africa, Jones having been brigade major in the $1^{\text {st }}$ Infantry Brigade. ${ }^{63}$

\section{The South African Contingent and deployment in Western Europe}

The brigade was recruited and mobilised in Potchefstroom in August and September 1915 and, although destined for Britain for further training, was rerouted to Egypt, where, in daring moves across the desert, they brought on the defeat of the Sanussi. This diversion away from Europe, albeit temporary, concerned some in South Africa. Maud Wyndham, believing that the tide in Europe was turning, hoped that the Brigade would still reach France 'for the last lap, \& march on Berlin. ${ }^{64}$ As the elements of the South African expeditionary force approached the Western Front, the South African parliament was prorogued after a session, described by her husband, the shadow defence minister, as most unwarlike.$^{65}$ Miners' phthisis and the university question seemed very South African, narrow and unimportant against the backdrop of a world war and the vital imperial issues with which the conflict was associated. ${ }^{66}$ Moreover, the political and military situation had not improved. Amidst Nationalist rhetoric and rumours of another rebellion, silence from German East Africa seemed ominous. If the campaign seemed to be stalling there, at least the news from France was more encouraging and, with the arrival of the South African expeditionary force, eyes in South Africa were firmly fixed on the Western Front. ${ }^{67}$

The $1^{\text {st }}$ South African Infantry Brigade arrived in Marseilles from 20 April 1916 and trained via Lyons to Versailles and then on to Abbeville. ${ }^{68}$ They arrived at Hazebrouck on 23 April where, for the first time, they experienced the artillery and aircraft activity then characteristic of the Western front. ${ }^{69}$ Over the next days the regiments were kitted out (they 
found that 'the gas helmets already in possession' were 'the wrong pattern \& unserviceable'). Much training was done and specifically in bayonet and trench fighting, bombing, attacking from trenches and 'moving up over ground swept by long range artillery fire to reinforce our own front line. ${ }^{, 70}$ The Brigade, having moved to Le Bizet, was strafed for the first time on 20 May and shelled repeatedly during the following days, ${ }^{71}$ experiencing their first 8-inch shell fire on 23 May. ${ }^{72}$ The Brigade moved, 'often a very trying journey through the mud', to Grovetown Valley on 30 June. $^{73}$

Two medical outfits accompanied the brigade: a field ambulance and a general hospital. ${ }^{74}$ The $1^{\text {st }}$ SA Field Ambulance moved to France in April 1916, following the conclusion of the Sanussi campaign in Egypt. The ambulance comprised three sections each with three medical officers and 60 other ranks: A Section was the headquarters unit under the unit commander; while $\mathrm{B}$ and $\mathrm{C}$ sections were each under the command of a major. The sections were divided into tent and bearer subsections or divisions. The bearer divisions were placed with the brigade, while the tent divisions were grouped into a dressing station for wounded able to march the approximate six kilometres from the front line; a main dressing station (at the divisional headquarters) some 15 kilometres from the front line; and a corps rest area, some 22 kilometres from the front, where recuperating patients and the warweary were taken up for final recovery. During the first phase of the battle of the Somme this was at Chateau Corbie. Medivac was in the form of a chain; wounded able to march and bearer casualties were taken by regimental bearers (responsible for field dressing) to the regimental medical post. Wounded able to march were taken from here to the dressing stations where they were further cared for by the staff of the Field Ambulance. Serious casualties were conveyed to $1^{\text {st }}$ SA General Hospital, by either car or barge. ${ }^{75}$

The South African General Hospital had a staff of 21 officers, two warrant officers, 43 nursing sisters and 142 other ranks; of whom Major William Lennox Gordon and Sergeant-Major Alex Knox have left small but rich collections of private papers. ${ }^{76}$ Knox, on arriving at Le Havre, noted what he termed 'several quaint customs of [the] French' - 'Traffic on right of road, open sanitary conveniences, dirty aspect of town, absence of proper drainage systems. ${ }^{, 77}$ At the rest camp, they were accommodated in 'Bell tents on boards with only one blanket. ${ }^{78}$ Abbeville, as Knox diarised, was 
an important railhead and the advanced base on the lines of communication in the Somme valley. It was also a quaint town with a 'nice old abbey which shewed marks of bombardment of war of 1570/1571 still on walls.' The hospital was 'camped on [a] site adjoining No 2 Stationary Hospital just outside town itself on Doullens-Amiens Road to Arras. Hospital very much worked since rush of July $1^{\text {st }}{ }^{, 79}$ The Ambulance was stationed there, temporarily only, Knox thought, to relive pressure on No 2 Stationary Hospital, on a 'very small piece of ground pitched up against large cornfield no chance of expansion.' Temporary buildings were erected for the operating theatre and kitchens, everything else in tents. ${ }^{80}$ The personnel underwent training on the nature of static warfare and the handling of casualties exposed to gas and braced themselves for the impending flood of patients that would follow the offensive. ${ }^{81}$

A considerable number of the artillerymen, serving with the five South African heavy batteries, had served in German South West. They mobilised for France as the $71^{\text {st }}, 72^{\text {nd }}, 73^{\text {rd }}, 74^{\text {th }}$ and $75^{\text {th }}$ Siege Batteries, R.G.A. In April 1916, a sixth battery, the $125^{\text {th }}$, was formed; while, early in 1918, two further batteries, the $542^{\text {nd }}$ and the $496^{\text {th }}$, were formed, but, when they arrived on the Western Front, they were broken up and their guns and personnel distributed among the other South African batteries. Also in 1918, the South African batteries were brought together and two South African brigades of heavy artillery were formed. ${ }^{82}$ However, as the historian of $72^{\text {nd }}$ Siege Battery noted, despite a 'wonderful keenness' displayed by all ranks, their 'training facilities were not of the best, for the guns at the disposal of the batteries were by no means up to date and new methods of warfare, suitable to the changed conditions on the Western front, were constantly being brought out.' Moreover, on arrival in Britain, it was announced that the batteries would be siege batteries, armed with six-inch howitzers, 'a new weapon then under construction', and affiliated to the Royal Garrison Artillery. ${ }^{83}$ This, Ernest Lane, one of the officers, thought a mistake:

'The greatest asset a South African has is his mobility and power to trek around, and they should have given us animal traction guns which are easier to learn how to handle, and then sent us off to some of the more distant and warmer scenes of war, whereas now we are siege artillery, tractor-drawn, with guns 96-inch howitzers that require the highest technical knowledge, and are likely to get to Flanders, where all the men will get horribly tucked up with cold. ${ }^{84}$ 
However, despite such gloomy forecasts, the batteries not only performed well, but enjoyed a life far more pleasant than that experienced by the brigade. The $73^{\text {rd }}$ Siege Battery, for example, was, in July 1916, 'comfortably billeted in farm buildings, while the guns were sited for camouflage purposes under fruit trees in an orchard' and 'at this time the surrounding country and village behind the lines showed little signs of war.' The battery's historian records that 'everything was fresh \& green', a countryside that was beautiful and to be enjoyed, 'and the general consensus of opinion throughout the Battery was that the war - to quote the popular expression - was "a good war". ${ }^{85}$ For the staff of the South African General Hospital, which moved to a location near Abbeville in mid-July, this was equally so. ${ }^{86}$ However, as the $73^{\text {rd }}$ s historian noted, 'conditions gradually became harder. ${ }^{, 87}$

The much-expected, great offensive commenced in the Somme sector on July 1. The South Africans all along the British sector of the line, witnessed something of the opening of the offensive, and were eager recipients of early news passed back from the immediate front by own forces as well as captured Germans. ${ }^{88}$ Before midday on July 1 , the first prisoners arrived in batches of fifty in Grovetown Valley. One prisoner told Bamford that the attack had been expected for the past four days. Their officers had told them that the Scottish divisions of the British Army were in front of them and that these divisions 'took no prisoners.' As a consequence, they had had no sleep for four days and nights! $!^{89}$ The massive bombardments, according to Bamford, were 'as intense an artillery bombardment as has ever been heard during the whole war on any front. ${ }^{90}$ And, with 'dead Bosches [Germans] ... lying everywhere in their trenches \& the ground beyond', the news was 'extremely good' and the South Africans were, Bamford records, 'anxious to be sent forward. ${ }^{91}$ Forming part of the corps reserve, they were eager to be in the thick of the action. Back in South Africa, a news-hungry public, aware that the great offensive had commenced, eagerly awaited the first reports. ${ }^{92}$

With the Allies attacking on all fronts, and the Russian advance supposedly going 'on and on like a song from Boris Gudonov ${ }^{93}$, Germany's defeat now seemed inevitable. Now, at last, the South Africans were doing something or were about to do something, and as part of an attack that, it seemed, would not 'fizzle out in a week. ${ }^{94}$ Moreover, the first newspaper 
reports, listing Allied successes, had an immediate effect in South Africa. Even De Burger broadcast South African success. The South African contingent it proclaimed capture Delville Wood, 'een van de belangrijkste centra is van de vijand in deze streek.' Moreover, noting the casualties, De Burger praised the troops:

'de manschappen zich van hun taak hadden gekweten op een wijze, waarover
Zuid-Afrika inderdaad trots kan zijn. Toen het ogenblik aanbrak, dat zij over de
verschansingen heen moesten springen en de zone binnengaan, welke door de
machinegeweren bestreken werd, was er met een die aarzelde. Er had slechts
weinig handeschudden plaats voor de sprong, en toen weergalmde de
zuidafrikaanse oorlogskreet. Enige minute later worstelden zij met de Hunnen
op leven en dood, gebruik makende van de bajonet, de kolf en de sable, maar
zij gingen vooruit over duitse lijken heen, over gebroken versperrigen,
slagijzers en zo voort.... roemrijke aandeel ...' 95

The good war news bolstered British prestige and that of the Botha government, and so quietened Boer dissatisfaction. Hertzog even published a letter in the press, calling for restraint among the extremists in his party. Other Nationalist leaders followed suite, expressing their intention of adhering to constitutional means in addressing grievances. ${ }^{96}$ English South Africans believed that nationalists around the empire were more careful and as a consequence of the fate of Irish nationalists in the wake of the Easter Rising. Yet, Maud Wyndham felt it 'so different being away from it all. ${ }^{97}$ She wanted to be in the midst of events, nursing soldiers in France or doing war work in London, where she could hear 'everything rather than being in [South Africa] missing things, even croaks \& grumbles [which] I suppose go on all the time even now when the news is so good - or at any rate veering slowly but surely in our favour.' ${ }^{98}$ Nonetheless, through July 1916, she thought the war news cheering, 'as progress really seems steady on our side all round.' It made a great difference to read the papers then. Formerly the allies 'were forever "retreating to straighten our line" or to "consolidate our position"., 99 Not for a moment doubting Germany's eventual defeat, Mrs Wyndham dreaded 'all the unhappiness every hour' brought. ${ }^{100}$ However, no matter how terrible, she felt that at least they now had something 'to show for [the losses]. ${ }^{101}$

By 8 July the Brigade was in the trenches on the edge of Bernafray Woods and over the ensuing days, during the battles for Bernafray Woods and Trones Woods and then Longueval and Delville Wood, casualties 
increased to the extent that the planned pattern of medical evacuation disintegrated. The casualties were numerous and the task of the bearers, having to carry wounded to the forward dressing station at Bernafray Wood, while also pummelled by the war, was enormous. SSgt Walsh, of the bearer section, collected a DCM. The movement of casualties from the dressing stations to the hospital was also no easy task; patients were despatched by train, motor vehicle and, for the most serious cases, by barge on the Somme. ${ }^{102}$

\begin{tabular}{|c|c|c|c|c|c|c|c|c|}
\hline \multirow[t]{2}{*}{ Battalion } & \multirow[t]{2}{*}{ Total } & 14 & 15 & 16 & 17 & 18 & 19 & 20 \\
\hline & & Jul & Jul & Jul & Jul & Jul & Jul & Jul \\
\hline $1^{\text {st }} \mathrm{SAI}$ & 192 & 13 & 2 & 27 & 26 & 114 & 5 & 5 \\
\hline $2^{\text {nd }} \mathrm{SAI}$ & 177 & 3 & 35 & 14 & 21 & 82 & 19 & 3 \\
\hline $3^{\text {rd }}$ SAI & 145 & 1 & 29 & 33 & 20 & 32 & 17 & 13 \\
\hline $4^{\text {th }}$ SAI & 156 & 1 & 28 & 40 & 27 & 32 & 25 & 3 \\
\hline Totals & 670 & 18 & 94 & 114 & 94 & 260 & 66 & 24 \\
\hline Percent & $100 \%$ & 3 & 14 & 17 & 14 & 39 & 10 & 3 \\
\hline
\end{tabular}

Table 3: The killed and missing of the $1^{\text {st }}$ South African Infantry Brigade, 14-20 July 1916.

(Source: I. Uys, Rollcall; The Delville Wood Story, p 195.)

Table 3 shows that thirty-nine percent of the casualties occurred on a single day, July 18, when, due to the arrival of large convoys of wounded, No 2 Stationary Hospital became more of a clearing station. ${ }^{103}$ Over the following days, as the casualties among the South African Infantry and South African Field Artillery increased, life at the South African hospital at Abbeville became more hectic. The hospital, now receptacle for overflow from the nearby British hospital as well as cases that arrived directly, faced several difficulties. The first of these was dealing with the British hospital system and, the second, the weather. Having just taken up 243 new cases on July 24, Knox records:

'Unsatisfactory methods by which these people kept their books made it extremely difficult at first to find out where we were. Everything in state of chaos. Temporary tents and operating theatres fixed up. Everything made exceedingly difficult and unpleasant by appearance of drizzling rain which left everything in about 3 inches of mud. ${ }^{104}$ 


\begin{tabular}{l|ccccc}
\hline & $\begin{array}{c}\text { Incoming } \\
\text { sick }\end{array}$ & $\begin{array}{c}\text { Incoming } \\
\text { wounded }\end{array}$ & $\begin{array}{c}\text { Surgery } \\
\text { performed }\end{array}$ & $\begin{array}{c}\text { Further } \\
\text { evacuation }\end{array}$ & $\begin{array}{c}\text { Number } \\
\text { of deaths } \\
\text { daily }\end{array}$ \\
\hline 23 July & & & & 118 & \\
24 July & 140 & 103 & & 118 & \\
25 July & $--------54-------~$ & & & 10 \\
26 July & & 43 & & 143 & \\
27 July & 10 & 53 & $57 \cdot$ & 143 \\
28 July & 10 & 53 & & & \\
\hline
\end{tabular}

Table 4: Through flow of patients at the South African General Hospital, Abbeville, July 1916

- Among these were many amputations resulting from gas gangrene due to corrosive shell and gas shell.

(Sources: Diary, July 1916, NASAP: A164 Sergeant Major Alex J. Knox Collection.)

Knox was 'fed up with [the] unsatisfactory way patients were left to the mercy of a willing and efficient but ill-equipped staff. ${ }^{, 105}$ The nature of the cases presented a third range of challenges. On July 24 the South African hospital lost two patients from gas gangrene following gunshot wounds, all 'fearful wounds' Knox thought. ${ }^{106}$ These varied from serious bullet and shell wounds to gassing and shell shock. ${ }^{107}$ The following day was 'absolute hell.' The medical officers were pushed to the limit in the operating tents, the orderlies in the wards, and the bearer division, under Major Pringle, worked to the limit conveying casualties to the field ambulance and on to the hospital. ${ }^{108}$ Knox, an administration sergeantmajor, spent a few hours on some days in the theatre when not engaged in the evacuation of patients to England and elsewhere. His diary gives an impression of the work of the hospital, although accurate data cannot be compiled from it. Nonetheless, with 243 new patients on 24 July and the evacuation of 118 on 23 July and the same number two days later, this must have been frenzied (table 4).

The medical officers and orderlies were perhaps the first to hear of the 'terrible suffering of the Brigade in the Wood. Roll call only revealed 80 of each regiment, percentage of officers killed very large. ${ }^{109}$ As shown in table 5 , all of the officers of the $2^{\text {nd }}$ and $3^{\text {rd }}$ regiments became casualties, a record, Buchan noted, that equalled that of the $1^{\text {st }}$ Coldstream and the $2^{\text {nd }}$ Royal 
Scots Fusiliers at First Ypres. ${ }^{110}$ When Gordon paid a visit to the $1^{\text {st }}$ Regiment on August 16, 1916, he found few of the friends he had made earlier in Egypt and France:

'There were not many of the men I knew. Most of the officers have been wounded. English \& Tempany have both commissions. Tempany is wounded \& English is away. Brown was killed, he had his commission for only a few minutes as he got it in the field. ${ }^{111}$

\begin{tabular}{|c|c|c|c|c|c|c|c|c|}
\hline \multirow[t]{2}{*}{ Regiment } & \multicolumn{2}{|c|}{ On 14 July } & \multicolumn{2}{|c|}{ On 20 July } & \multicolumn{2}{|c|}{$\begin{array}{c}\text { Casualties } \\
\text { between } 14-20 \\
\text { July }\end{array}$} & \multicolumn{2}{|c|}{$\begin{array}{c}\text { Percentage of } \\
\text { casualties }\end{array}$} \\
\hline & 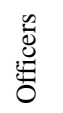 & 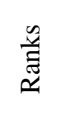 & $\underbrace{\stackrel{0}{0}}_{0}$ & 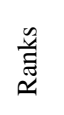 & $\underbrace{\stackrel{0}{0}}_{0}$ & $\begin{array}{l}\text { 華 } \\
\text { こี }\end{array}$ & $\underbrace{\infty}_{0}$ & 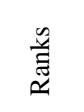 \\
\hline $1^{\text {st }} \mathrm{SAI}$ & 31 & 748 & 8 & 213 & 23 & 535 & $74 \%$ & $71.5 \%$ \\
\hline $2^{\text {nd }} S A I$ & 26 & 669 & 2 & 185 & 26 & 484 & $100 \%$ & $72 \%$ \\
\hline $3^{\text {rd }}$ SAI & 29 & 847 & 1 & 104 & 28 & 743 & $96.5 \%$ & $88 \%$ \\
\hline $4^{\text {th }}$ SAI & 27 & 672 & 7 & 183 & 20 & 489 & $74 \%$ & $73 \%$ \\
\hline M.G. Coy & 8 & 96 & - & 17 & 8 & 79 & $100 \%$ & $82 \%$ \\
\hline Totals & 121 & 3032 & 18 & 702 & 105 & 2330 & $87.5 \%$ & $77 \%$ \\
\hline
\end{tabular}

Table 5: South African casualties in Longueval and Delville Wood, $14-20$ July 1916: fighting strength less all detached men

- These two officers were wounded but returned to duty.

Note: A considerable number of officers and other ranks, who were slightly wounded in Bernafray Wood and the trenches between Maricourt and Montauban, returned to duty within a few days and were killed or wounded in the later fighting. These Lukin only showed once as casualties.

(Source: Schedule B to Despatch No III by Brig Gen H.T. Lukin, 14 Aug 1916, SANDF Documentation Centre: WO1DA, box 5, South African Infantry Brigade Headquarters, July 1916, Operations on the Somme.)

The $1^{\text {st }}$ SA Infantry Brigade and its field ambulance were withdrawn from the Longueval sector of the Somme front on July 20. The nature of the war on the Western Front, static and including the shifting of military units up and down the front and into reserve and back again makes the South African deployment in France seem complicated. The artillery batteries 
were also withdrawn at times, only to be moved back into the line, sometimes to the same place, a few days or a few weeks later. However, two events loom large in the South African experience of the Somme campaign, marked purely by the intensity of the experience and the scale of the human losses. They are Delville Wood, where, between July 1 and July 20, the South Africans suffered 3155 casualties, and the Butte de Warlincourt, where, that October, a further 1150 losses were sustained by the infantry brigade (table 6).

\begin{tabular}{l|cc}
\hline & $\begin{array}{c}\text { Delville Wood } \\
\text { 1-20 July 1916 }\end{array}$ & $\begin{array}{c}\text { Butte de Warlincourt } \\
\text { 9-19 Oct 1916 }\end{array}$ \\
\hline Killed & 457 & \\
Death assumed & 186 & \\
Died of wounds & 120 & \\
Wounded & 1476 & \\
Prisoners & 297 & 1150 \\
\hline Total Casualties & 3155 & \\
\hline
\end{tabular}

Table 6: South African Infantry Brigade casualties: the two most expensive months.

The heavy casualties sustained by the Brigade during July made the resumption of the recruitment of reinforcements a 'most pressing necessity. ${ }^{112}$ In fact, on 4 July 1916, before the Brigade entered the frontline, the Army Council had raised the matter of recruiting to fill the coming losses. A monthly intake of $10 \%$ of establishment was suggested. ${ }^{113}$ Botha postponed his answer. He left for German East Africa on July 11 to consult with Smuts. ${ }^{114}$ By early August, he had still not replied. London probed Pretoria again. ${ }^{115}$ Bourne, the civilian head of the defence department, doubted whether they would be able to recruit much more than Smuts' requirements for East Africa. However, recognising that the situation regarding the Brigade, owing to the very heavy casualties, was grave, Bourne suggested that they would soon know whether the East Africa campaign was likely be prolonged and, if so, on Botha's return, they would make a special recruiting effort, which, if successful, might even produce some 500 to 1000 recruits for France, in addition to meeting the need for troops in Tanganyika. ${ }^{116}$ 
Yet Botha, persistently unrealistic, hoped still to supply a complete division with reserves for France. An early end to the Tanganyika campaign would release men for Europe. Buxton, however, shared Bourne's caution. The governor-general warned Botha that, if South Africa was to field a division, he would need, in addition to the brigade already in France, a further twenty-eight thousand recruits over the next six months. Furthermore, as Buxton noted, mounted troops, even with rebellion and German West and East Africa experience, would not be of much use in France. A South African Infantry Division was, therefore, out of the question and all that could be done to increase South African visibility in France was to brigade the multifarious South African units together in the same division. ${ }^{117}$

Botha returned from Tanganyika knowing that the campaign there was not at an end. He knew too that there was 'no reasonable prospect of reopening recruiting for the $1^{\text {st }}$ South African Infantry brigade with any chance of success, and at the same time of keeping pace with the requirements of Union Imperial Service Infantry Units in East Africa for reinforcements to replace wastage. ${ }^{118}$ He faced two choices. Firstly, await a successful conclusion to the campaign in Tanganyika before reopening the recruitment drives and then raise the additional units allowing the formation of a complete South African Division. ${ }^{119}$ Or, secondly, recruit concurrently for both Smuts and Lukin. Botha, wanting to cover both his sub-imperial and prestige objectives, opted for the second.

Two recruiting campaigns started on September 1. However, amidst the outcry over pay ${ }^{120}$ and complaints regarding the irregularity of supply in Tanganyika, far fewer recruits than were expected came forward. Since Botha's appeal on August 17, 2084 recruits were obtained, but only 146 for the Brigade in France. This fell far short of the draft of 600, which was the minimum requirement. Yet, the Union cabinet thought the general result of the appeal neither unsatisfactory nor surprising. The recruits had gravitated to East Africa for two reasons: they 'felt that the first call on them was for the arduous campaign close to their gates' and the fact that East Africa offered a better rate of pay. Although recruitment for the brigade in France was of the utmost importance, only 100 infantry left for Europe that October. The ministers requested the Army Council to 'understand the 
position' and the 'difficult circumstances' under which these arrangements were made. ${ }^{121}$

By September the offensive on the Somme had clearly petered out. This and the mixed reports from German East Africa, where the progress was slow and the complaints many, did much to undermine Botha's position in South Africa. The failure of the recruitment drives was a symptom of this. To return to the question posed by Lt Cyril Newton-Thompson on 7 July 1916, was 'the game worth the candle. ${ }^{122}$ The men sent abroad seemed to be paying a tremendous price, exposed either to the malarial jungles and rigours of East Africa or the trenches and brutalisation of industrial warfare in France.

\section{The Legacies of the Western Front}

\begin{tabular}{|c|c|c|c|c|c|c|c|}
\hline & 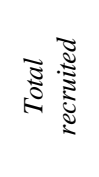 & 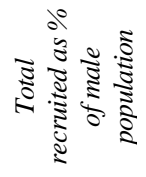 & 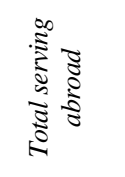 & 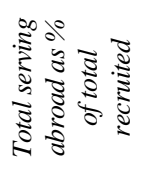 & 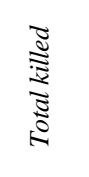 & 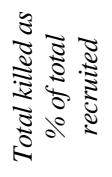 & 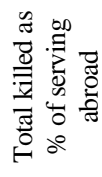 \\
\hline UK & & 22 & & & & & \\
\hline Canada & 628,964 & 14 & 458,218 & 73 & 56,639 & 9 & 12 \\
\hline Australia & 412,953 & 14 & 331,814 & 80 & 59,330 & 14 & 18 \\
\hline $\mathrm{NZ}$ & 128,525 & 20 & 112,223 & 87 & 16,711 & 13 & 15 \\
\hline S. Africa & 136,070 & $10 \star$ & 76,184 & 56 & 7,121 & 5 & 9 \\
\hline India & 683,149 & & $1,096,013$ & & 65,056 & & \\
\hline
\end{tabular}

Table 7: The contribution of imperial and dominion troops to the war effort, 1914-1918

- This figure is a percentage of the white male population.

(Source: adapted from A.S. Thompson, Imperial Britain, p 158.)

For the allied powers, the ostensible victors, victory was bittersweet. For South Africa, this was little different. Although South Africa emerged physically unscathed, the price tag, in money and sacrifice, had been high. ${ }^{123}$ Although South African casualties were comparatively low, when compared with the other dominions (table 7), most of the 7121 killed had died on the Western Front. For South Africa, a country accustomed to limited wars and low ownforce casualties, these losses were unacceptable. Furthermore, the war, 
together with the rebellion and rumour of rebellion, had come at a political cost, increasing as it did popular suspicion of government, leaders, and institutions like the military. It discredited Botha and Smuts, the wartime ministers, and, although temporarily aligning South Africa with the allied powers, estranged Smuts and those of broader vision from the mass of Afrikaners.

\section{Coming to terms with the carnage}

This was, of course, not a phenomenon uniquely South African. Generals, across the board, were blamed for the costly failures of the war. Military commanders on all sides were criticised and quite severely, for the apparent waste of human life in a succession of offensives that gained little, while they, it would said, were safe, back at their HQ's enjoying the best France could offer. Many South Africans saw Delville Wood as an example of this callousness. Maud Wyndham went a step further and blamed the Allied generals for these military 'muddles' and accused many of them of being incompetent and lacking in the mental ability needed to effect a breakthrough. She was even more critical towards the political leaders, who she accused of not supporting the generals at the front with a workable and realistic grand strategy to win the war. 'Providence', she lamented, 'has not given us a Chatham and a Marlborough to guide us thro this period., ${ }^{124}$

Yet, although it was 'no use girding against the poor minnows we have got', Mrs Wyndham was convinced, as many South Africans were, that 'there [were] things even a minnow might avoid. ${ }^{125}$ The South African leadership, although praised in Britain for their stance, was at times, for both the British sector in South Africa as well as the Afrikaner right, an object for amusement or of scorn. Furthermore, the politicians were blamed for not facilitating a solution to the deadlock. The politicians, Newton-Thompson complained, were 'prepared to fight to the last drop of blood of the soldiers at the front. ${ }^{126}$ And they did not seem to have any answers to the problems, answers which soldiers at the front seemed to have had. To quote NewtonThompson, who admitted he did 'not know enough about the interdependence of the German armies to know what effect our attack at the Somme has in helping the attack of our allies in other parts':

'The Allies must realize that if they are going to win this war (i.e. hands down) they must have roughly 3 men in the field to every two which the Germans \& Austrians have \& they must have 3 guns to every two German guns; and we must 
count 3 Italians as one man in reckoning our strength. If we settle down to this we shall win in the end. The hordes of Russia must be marshalled \& discipline; the wavering Italians must be exhorted to action, \& the drooping spirits of the French must be revived; above all John Bull must plunge deeper \& deeper into debt \& must be prepared to get over another million of his stoutest sons killed \& wounded in battle. Are we prepared to do all this? I wonder. ${ }^{127}$

Politicians seemed the true enemy of the soldier, whose collective innocence and sacrifice was memorialised on plinth and in churches as almost Christ-like. Emily Hobhouse, writing in August 1914, blamed the politicians, 'who make troubles', for callously sending the troops in to be killed. ${ }^{128}$ N.W. Nichol, vocalising a popular sentiment three years later, reckoned that 'there is no doubt the politicians ought to get it in the neck, it's an awful shame that the soldiers should be the only ones to suffer. ${ }^{129}$ They had been exposed to the brutality of warfare in Europe, without, it was thought, proper leadership, and without proper training. Colonial volunteers ought not to have been thrown into the line against German professional militarism.

In the very different climate of the mid-1920s, the debate over the war that had not fully taken place at the war's end assumed a central place in the larger and at times quite vocal debate over South African foreign policy. The basic issues remained. Firstly, there was the question of the morality of the intervention. Ought South Africa to involve herself in foreign, imperial wars? And, closely associated with this, was the aversion for technological warfare, for the materielschacht. ${ }^{130}$ Smuts himself wrote:

'There is much to make us profoundly sad and almost to despair of the future of the race when we see our greatest intellectual and scientific discoveries turned like so many daggers at the heart of civilization., ${ }^{131}$

The individual had to be recovered and returned to the centre stage; something it seemed could be done more easily in Africa, where human skill seemed to count for more. This raises the second matter, the wisdom of the intervention. Europe, simply stated, was not the place for South African military intervention. Warfare in Europe had to be avoided and, as a result, after 1924, the Union Defence Force refocused on Africa, where asymmetry would be to her advantage and was more suited to the South African way of war. The Somme had been geographically foreign, and its circumstances militarily unfamiliar. ${ }^{132}$ 
The military 'lessons'

South Africa too went through several processes to deduce so-called 'lessons.' The first of these was conducted under Lukin and at the behest of the commander of the $9^{\text {th }}$ Division:

'The Division has done well in the recent fighting. We must now, while our several experiences are fresh in our memories, dig out and clarify by close discussion the lessons of the fighting so that we may do even better in the future.'

Furse called for frankness and an inclusive process, based not on 'fault finding' but 'fact finding', so that 'the best way of dealing with similar situations in the future' could be discovered. ${ }^{133} \mathrm{~A}$ list of 'subjects for enquiry' was distributed and the South African report addressing numerous tactical matters, probably written by James Mitchell-Baker, the Brigade Major, was submitted by Lukin on 3 August $1916 .{ }^{134}$

Several military publications were produced in South Africa between the two world wars. These included several drill manuals and textbooks ${ }^{135}$ as well as the official history of the Great War, which appeared in 1924. The last, described by Agar-Hamilton decades later as having 'no outstanding merit', ${ }^{136}$ was a overall, macro history and was a tremendous disappointment to MajorGeneral Jack Collyer, a wartime chief of the general staff, who had hoped for a utilitarian history that would draw lessons and make instruction material for officers at the South African Military College. ${ }^{137}$ In view of this, Collyer, who was incidentally Lukin's brother-in-law, bridged the gap himself with two textbooks, one on the German South West Africa campaign (1937) and another on the German East African campaign (1939).

As far as Collyer was concerned European textbooks were irrelevant in Africa and he set about producing standard texts for warfare in Africa, deducing the 'lessons' in the nineteenth-century utilitarian, didactic fashion, neatly setout for the instruction of officers at the South African Military College. ${ }^{138}$ Although, many of his 'lessons' were misinformed, they provide a rare insight into inter-war South African military thinking. Collyer, thought by some to be 'the Liddell-Hart of South Africa ${ }^{139}$, pointed out and quite rightly that South Africa had not been prepared for war in 1914 and his first call was for the systematic collection and updating of information in Sub-Saharan Africa and 
'the teaching of experience', emphasising both the importance of military history and the collection of accurate military information. Foreknowledge would lessen the difficulty in gaining strategic surprise, shorten campaigning in tropical Africa, and so limit casualties. However, Collyer, a mounted infantryman with fifty years of service in Africa, was clearly not a man for modern devices. He highlighted the problems of air power rather than possibilities ${ }^{140}$ and discounted the immediate value of mechanised transport in Africa, only mounted troops could be relied upon, and so provided unwittingly a theoretical basis for the 'bush cart' policy of Oswald Pirow, who became defence minister in 1933. ${ }^{141}$ The type of operations undertaken by South Africa in East Africa in 1940 and North Africa in 1941 had simply not been contemplated.

\section{South Africa and the neutrality question}

Nowhere was the impact of the Western Front for South Africa greater than on the nation's foreign policy. The war shattered any possibility for postrebellion, national reconciliation and left South Africans confused and deeply divided on the goals to be pursued and methods used. Even before it had ended, the traumatic experience of the war, combined with the apparent improvement of relations between Afrikaners and some English-South Africans, and a growing preoccupation with domestic problems, produced a drastic reordering of national priorities. Smuts had placed foreign policy consistently near the top of the ranking of national concerns, but by Hertzog's first term it was placed well down on the list.

The National party, while in opposition, equated military and industrial power with Smuts, holism and a Greater Britain. ${ }^{142}$ The war experience had provoked strong opposition to military intervention abroad, particularly in aid of Britain and in support of objects perceived to be British or imperial rather than South African. Hertzog, who came to power in 1924 and remained in Tuinhuis until September 1939, would avoid foreign deployments, especially if these were 'outside Africa.' While still in opposition, he had opposed possible South African support for Britain during the Chanak crisis. ${ }^{143}$ In a speech at Clanwilliam, Dr D.F. Malan (NP, MP Calvinia) denied that South Africa had any agreement or obligation, legal or moral, to help Britain with her wars: 'Die Dardanelle is nie ' $n$ druppel van ons bloed of ' $n$ sjïeling van ons geld wêrd nie, en Suidafrika 
behoort hom neutral te verklaar. ${ }^{144}$ Over the following month, the National Party made use of every opportunity to again lay down their traditional policy of neutrality. On 22 September 1922, Tielman Roos (NP, MP Lichtenburg) was quoted in the press:

'Ons is absoluut daarteen gekant om die Unie te stoot in die bynes van Eropese en Asiatiese politiek en oorloë. Dus sal die Nasionale Party veg teen die versending van ' $n$ enkele Afrikaner-Engels- of Afrikaans-sprekende - en die uitgawe van 'n enkele pennie in verband daarmee. Ons mede-burgers van Engels, van Hollands en van ander afstamming, is vir ons te veel wêrd om hulle daar te verloor. Ons het hulle nodig om Suid-Afrika op te voer., ${ }^{145}$

The indifference and tendency toward withdrawal so manifest immediately after the war also declined in the following decades as the Nationalists grappled with difficulty of having to marry ideology and reality. With time three broad principles emerged. Firstly, the zone of deployment for the UDF was Africa. It would only be applied for the immediate defence of South Africa, where it would enjoy the advantages of technological asymmetry. By implication it also meant that the UDF would never again be deployed to Europe and European warfare, as such, would be avoided. Secondly, the UDF would be a small force, well-equipped for its purpose. There would be an emphasis on mounted infantry and a small air force, but little room for mechanisation as the lack of infrastructure in Africa pointed to little use for it. And, finally, the UDF would nonetheless be sufficiently lethal to deal with internal conflict, sufficiently potent not to run the risk of many own-force casualties. This is seem at Bulhoek, the Bondelswarts uprising, the Rand revolt of 1922, and the Ipumbu uprising of 1931, where the UDF, deployed in three of these cases to conduct punitive operations, had great psychological advantage.

Nonetheless, the UDF was, like other forces, demobilised after November 1918 and large-scale rust-out took place from 1924, with the result that when the Second World War broke out in 1939, the Permanent and Active Citizen Forces were severely understrength and the Commandos, pet of the nationalist government, although reasonably equipped for their purpose, being rurally based and overwhelmingly Afrikaans and were not expected to support another 'British' war. Furthermore, much of the doctrine had not kept pace with technological developments. Mechanisation of ground forces and the application of new technology contrasted sharply with developments in Europe. Although South Africa had the industrial capacity for the development of 
armour and mechanised forces, arguments based upon the nature of potential enemy forces, poor infrastructure and terrain inaccessibility combined with government policy and financial stringency resulted in nothing being done. Southern Africa, the focus of South African defence policy, was also thought to be unfavourable for mechanised warfare. Inadequate roads and multifarious geographic features concentrated energy on the development of the air arm for operations in Africa and a system of coastal defences to repel a sea assault, as well as a mix of British and Boer-type infantry supported by field artillery. As a result, an expeditionary force had to be prepared from scratch after September 1939 and the first South Africans to serve in the Second World War only left the country in July 1940.

\section{Conclusion}

The First World War, fought for the future of liberal democracy, was necessary and had both meaning and purpose. It was not a futile waste, but fought for a cause. Yet, as Niall Ferguson has argued in The Pity of War, the war 'derailed the benign civilising mission of the British Empire.' Britain emerged from the conflict depleted and exhausted. This was the onset of retreat from empire, an uncomfortable reality that the most ardent imperialists around the Commonwealth had to accept after 1945. The moment the South African Unionists chose to seize, to draw South Africa closer to a Greater Britain, was ironically also the vehicle of the start of imperial decline. In South Africa the Nationalists, then largely still the Afrikaans far-right, came out strong and ready to take power with Labour in 1924.

The War differed from previous conflicts in terms of scope and intensity. Nations mobilised fully and the accompanying devastation unparalleled and the death toll unprecedented. For South Africa, attuned to small wars, limited 'native' campaigns, chiefly of pacification, and accustomed to low own-force casualties, the change to total warfare and the experience of the Western Front was cataclysmic. The South African stand at Longueval and Delville Wood lasted one week, almost precisely; from midday on July 14 to dusk on July 20, 1916. This was the second most expensive week in South African military history, surpassed only in 1942 with the surrender at Tobruk. 
More than a quarter of a million South Africans served on the different fronts: involving nearly twenty percent of the white male population. More than thirty thousand South Africans experienced the horror of trench warfare on the Western Front. Post-war governments wished to avoid such carnage in future and confine future operations to the continent of Africa. Politicians of all hue were determined not to send South Africans into the trenches again. As late as 1939, the general staff did not foresee the eventuality of South Africans fighting in the European theatre again and this was included in the Smuts formula of September 1939. The campaigns in German South West and East Africa, on the other hand, were, as John Buchan noted, 'frontier wars, fought for the immediate defence of her borders and her local interests. ${ }^{146}$ Africa south of the equator was the presumed zone of deployment for the UDF, which would be a small force, but, sufficiently lethal and psychologically overwhelming, and well-equipped for this purpose.

1 "Fresh Call for Volunteers; Union's Second 'Little Bit'; Mostly Infantry Wanted; Details of Terms of Service”. Rand Daily Mail, 21 Jul 1915.

2 On popular imperialism in South Africa see Bill Nasson. "A great divide: popular responses to the Great War in South Africa”. War \& Society, XII 1994; Bill Nasson. "War opinion in South Africa, 1914". Journal of Imperial and Commonwealth History XXIII. 1995; LWF Grundlingh. "Die Engelssprekende Suid-Afrikaners se reaksie op die uitbreek van die Eerste Wêreldoorlog” (MA, UOVS, 1978). For Britain, see A Marwick. The Deluge: British Society and the First World War. Boston and Toronto: Little Brown, 1965. 29-39; as well as JM MacKenzie, ed., Propaganda and empire: The manipulation of British public opinion, 1880-1960. Manchester: Manchester Univeristy Press, 1984; and WJ Reader. 'At duty's call': A study in obsolete patriotism. Manchester: Manchester University Press, 1988. William Carter to Algernon Lawley, 19 Mar 1915, AB186 Archbishop Carter Letters, William Cullen Library, University of the Witwatersrand (Wits). Lt Cyril Newton-Thompson to Joyce Nettelfold, 7 Jul 1916, BC643 Joyce Newton-Thompson Collection, B1.43, University of Cape Town Libraries (UCT).

5 "Union's Roll of Honour. Deathless Deeds at Delville Wood. Musical Memorial Service in the City Hall. Mr Merriman on South Africa's Heritage”. Cape Times, 19 July 1917, p. 6. See also, Programme, Delville Wood Day, PM 1/1/48, file 4/84/1917 European War, SA Brigade Successes, National Archives of South Africa, Pretoria (NASAP).

"Union's Roll of Honour. Deathless Deeds at Delville Wood. Musical Memorial Service in the City Hall. Mr Merriman on South Africa’s Heritage”. Cape Times, 19 Jul 1917, p. 6. 
Circular from Major General W Furse to his brigade commanders, 21 July 1916, and General H. Rawlinson to Furse, 25 July 1916, WO1DA, box 5, War Diary of SA Inf Bde HQ, July 1916, SANDF Documentation Centre. G Mills and D Williams. Seven Battles that Shaped South Africa. Cape Town: Tafelberg, 2006. John Buchan. The History of the South African Forces in France. London, 1920; reprinted Nashville: Battery Press, 1992, 11.

Buchan op. cit.; General Staff, South Africa and the Great War: Official History. Pretoria: Government Printer, 1924; I Uys. Rollcall; The Delville Wood Story. Johannesburg: Uys, 1991; P Digby. Pyramids and Poppies: The $1^{\text {st }}$ SA Infantry Brigade in Libya, France and Flanders 1915-1919. Rivonia: Ashanti, 1993. N Clothier. Black Valour. Pietermaritzburg: University of Natal Press, 1987; and Ian Gleeson. The Unknown Force: Black, Indian and Coloured Soldiers Through Two World Wars. Rivonia: Ashanti, 1994 explore, inter alia, the story of the SANLC in France.

Bill Nasson. "Delville Wood and South African Great War Commemoration". English Historical Review cxix/480. 2004; and Bill Nasson. Springboks on the Somme; South Africa in the Great War 1914-1918. Johannesburg: Penguin, 2007.

M Howard. "The First World War Reconsidered”. In J Winter, G Parker and MR Habeck, eds., The Great War and the Twentieth Century. New Haven and London: Yale University Press, 2000, 14. De Burger, taking a surprisingly neutral line, described it too as 'De Grote Volkerenstrijd'. See, for example, De Burger, 29 Feb 1916, 20 Mar 1916 and 17 Jul 1916.

See, for example, PM 1/1/32, file 4/97/1914 War German South West Expedition \& Supply of Ammunition \& Guns; and SANDF Documentation Centre: DC, Box 573, file D.9199 European Crisis General, vol 7, NASAP. 'De Britse-Duitse Oorlog' (The Anglo-German War), diary of FS Malan, 7 Aug to 10 Aug 1914, A583 FS Malan Collection, vol 22, National Archives of South Africa, Cape Town (NASAC). MT Steyn to JC Smuts, 31 Jul 1914, in WK Hancock and J van der Poel, eds., Selections from the Smuts Papers, vol III: June 1910 - November 1918. Cambridge, Cambridge University Press, 1966, p. 184. PF van der Schyff, "Die Unioniste Party in die Suid-Afrikaanse politiek, 19101921” (Unpub M.A. thesis, P.U. for C.H.E., 1964), 72. Diary of FS Malan, 9 Aug 1914, A583 FS Malan Collection, vol 22, NASAC. Buchan op. cit., p. 13. See also Emily Hobhouse to Smuts, 8 Aug 1914, in Hancock and Van der Poel, eds., op. cit., p. 185. Buchan op. cit., p. 13. Hugh Wyndham to Lady Leconfield, 13 Aug 1914, Petworth House Archives (PHA), West Sussex Record Office, Chichester (WSRO). Lord Harcourt to Lord de Villiers, 8 Aug and 23 Aug 1914, PM 1/1/32, file 4/97/1914 War German South West Expedition \& Supply of Ammunition \& Guns, NASAP. See also Diary of FS Malan, 7 Aug to 10 Aug 1914, A.583 FS Malan Collection, vol 22, NASAC. For a general statement, converging much of the current debate and adding several new insights, see H Strachan, The First World War in Africa. Oxford: Oxford University Press, 2004, 61 passim. 
22

Lord Harcourt to Lord de Villiers, 8 Aug 1914 and 23 Aug 1914, PM 1/1/32, file 4/97/1914 War German South West Expedition \& Supply of Ammunition \& Guns, NASAP.

'De Britse-Duitse Oorlog' (The Anglo-German War), diary of FS Malan, 7 Aug to 10 Aug 1914, A.583 FS Malan Collection, vol 22, NASAC; and SB Spies. "The Outbreak of the First World War and the Botha Government". South African Historical Journal 1. 1969. p. 47.

Hugh Wyndham to Lady Leconfield, 13 Aug 1914, PHA, WSRO. These sentiments were also held by Carter. See William Carter to Algernon Lawley, 13 Aug 1914, AB186 Archbishop Carter Letters, Wits.

Maud Wyndham to Lord Cobham, 11 Aug 1914, Hagley Hall Archives, Worcestershire (HHA) 2/36/45.

Nasson. 'A great divide', p. 50. See also NG Garson. "South Africa and World War 1”. Journal of Imperial and Commonwealth History VIII. 1979. pp. 69-70. The rebellion and the often difficult position of the Loyal Afrikaners has been treated excellently by Kent Fedorowich, "Sleeping with the Lion? The Loyal Afrikaners and the South African Rebellion of 1914-15". South African Historical Journal 49. 2003. pp. 71-95.

Hugh Wyndham to Lady Leconfield, 9 Sep 1915, PHA, WSRO.

Hugh Wyndham to Lady Leconfield, 30 Sep 1915, PHA, WSRO.

These blunders are well-catalogued in Strachan op.cit., p. 64 passim. They include Smuts' overconfidence and the lapsing of a month before parliament was called; the lack of ammunition in South Africa and poor cooperation with the Royal Navy; speculation and the dualities of the South Africa Defence Act; and, genuine confusion resulting from the absence of a central staff and command organisation, and contingency plans, and all these were exacerbated by an initial intelligence failure.

Maud Wyndham to Lady Leconfield, 30 May 1916, PHA, WSRO.

GG 586, file 9/51/52 War 1914-16: Trade. Exportation of certain forms of steel, NASAP. See also the rest of this series of files.

GG 667, file 9/93/1 War 1914: Imperial Army. Suggested recruiting of men in South Africa for enlistment in the "New Army", NASAP. See also BC915 James Metcalfe Papers, A1 to A5, UCT.

Buchan op.cit., p. 15. See Dawid Graaff to Smuts, 8 Jun 1915, and Smuts to Graaff, 14 Jun 1915, in Hancock and Van der Poel, eds., op.cit., pp. 296, 298.

Smuts to Buxton, 21 June 1915, GG 667, file 9/93/7 War 1914-16: Imperial Army. South African Overseas Expeditionary Force, NASAP.

Smuts to Buxton, 24 June 1915, GG 667, file 9/93/7 War 1914-16: Imperial Army. South African Overseas Expeditionary Force, NASAP.

Lord Buxton to Smuts, 9 Jul 1915, in Hancock and Van der Poel, eds., op. cit., p. 303.

JX Merriman to Smuts, 6 Sep 1915, in Hancock and Van der Poel, eds., op. cit., p. 311.

D.P. Graaff to Smuts, 8 Jun 1915, in Hancock and Van der Poel, eds., op. cit., p. 296.

Graaff to Smuts, 8 Jun 1915, and, in particular, Merriman to Smuts, 6 Aug 1915, in Hancock and Van der Poel, eds., op. cit., pp. 296, 307-8. 
40

Smuts to Merriman, 30 Aug 1915, in Hancock and Van der Poel, eds., op. cit., p. 310.

Bonar Law to Buxton, 8 Nov 1915, and Smuts to Buxton, 10 Nov 1915, GG 668, file 9/93/24 War 1914-15: Army, Imperial. Overseas Expeditionary Force, NASAP.

Smuts to Buxton, 24 June 1915, GG 667, file 9/93/7 War 1914-16: Imperial Army. South African Overseas Expeditionary Force, NASAP.

Smuts to Buxton, 19 July 1915, GG 667, file 9/93/7 War 1914-16: Imperial Army. South African Overseas Expeditionary Force, NASAP.

Smuts to Buxton, 14 July 1915, GG 667, file 9/93/7 War 1914-16: Imperial Army. South African Overseas Expeditionary Force, NASAP. It was also decided, to settle public uneasiness, to publish official correspondence relating to the raising and deployment of the South African contingents. See GG 668, file $9 / 93 / 26$, NASAP.

"Fresh Call for Volunteers; Union's Second 'Little Bit'; Mostly Infantry Wanted; Details of Terms of Service”. Rand Daily Mail, 21 Jul 1915; "Heavy Artillery in Flanders; General Terms of Service”. Rand Daily Mail, 22 Jul 1915; and "Wanted in Europe; Call for Heavy Artillery, Opening for South Africans". Rand Daily Mail, 22 Jul 1915.

See the series of applications and expressions of interest in the series of files under reference DC 128/958/9199 and titled 'Applications for Overseas Contingent' in DC, Boxes 689, 690 and 691, SANDF Documentation Centre. At the first rumours, the town clerk of Grahamstown offered his 'commonage, both wooded and otherwise for a training ground' for the overseas contingent. Town Clerk, Grahamstown to Minister of Defence, 13 July 1915, DC, Box 690, file DC 128/958/9199 Applications for Overseas Contingent, SANDF Documentation Centre.

Louis Matthews to Nicholson, QMG's office, 25 Nov 1915, DC, Box 690, file DC 128/958/9199 Applications for Overseas Contingent, SANDF Documentation Centre.

Buchan op. cit., p. 14.

Bonar Law to Buxton, 24 Jul 1915, and Botha to Buxton, 10 Aug 1915, GG 667, file 9/93/7 War 1914-16: Imperial Army. South African Overseas Expeditionary Force, NASAP.

Botha to Buxton, 10 Aug 1915, GG 667, file 9/93/7 War 1914-16: Imperial Army. South African Overseas Expeditionary Force, NASAP.

The infantrymen would each carry a rifle M.L.E. with oil bottle, pull through and sight protector, sword bayonet, pattern ' 88 with scabbard, and two hundred rounds of mark VI ammunition per rifle. See Botha to Buxton, 19 Aug 1915, GG 667, file 9/93/7 War 1914-16: Imperial Army. South African Overseas Expeditionary Force, NASAP.

Bonar Law to Buxton, 17 July 1915, GG 667, file 9/93/7 War 1914-16: Imperial Army. South African Overseas Expeditionary Force, NASAP.

Buchan op. cit., p. 16.

Uys op. cit., p. 5.

Buchan op. cit., p. 15. 
I van der Waag. "Smuts's Generals: Towards a First Portrait of the South African High Command, 1912-1948”. War in History 18/1. 2011. pp. 33-61.

Imperial distrust of certain Boer officers, confirmed by the outbreak of rebellion in 1914, exacerbated poor relations. To many a British officer, South Africa was still perceived as the beaten enemy of the 1899-1902 War - even as late as 1917. See, for example, DC, Box 1142, file DCDB 2394/7 Suggested recall of Brigadier General Cavendish GOC South African Military Command and appointment of General Martyn, SANDF Documentation Centre. Speech made by General Cavendish at a meeting of the St. John's Ambulance on 2 Nov 1917, in which he described General JC Smuts, Union Minister of Defence, as 'that modern miracle' who 'for (the) beaten enemy ... had a very nasty knack of asserting himself at times.'

Carter to Algernon Lawley, 18 Dec 1914, AB186 Archbishop William Carter Letters, Wits.

A reader of the Transvaal Leader thought that the field commanders lacked military qualifications and military knowledge, and would not reach 'the rank of lance corporal in the regular army.' 'The idea', he continued, 'that any fool can be a soldier and take command of men disappeared centuries ago.' Editor of Transvaal Leader to Smuts, 7 Jan 1915, DC, Box 573, file D.9199 European Crisis General, vol 7, SANDF Documentation Centre. The first reverses in German South West seemed to confirm the worst of these fears.

Carter to Algernon Lawley, 11 Feb 1915, AB186 Archbishop Carter Letters, Wits. See also Hugh Wyndham to Lady Leconfield, 17 Feb 1916, PHA, WSRO, as well Ross Anderson, Forgotten Front: The East African Campaign 1914-1918. Stroud: Tempus, 2004.

Lukin, in addition to his colonial experience, had enhanced his reputation in GSWA in 1915 and then in Egypt in early 1916. Even De Burger, a strongly nationalist paper, broadcast Lukin's success. See, for example, "In Egypte; Generaal Lukins Kolonne; De vijand op de vlucht”. De Burger, 29 Feb 1916. FM Douglas Haig to The Secretary, War Office, 20 Mar 1918, WO 374/43230, The National Archives of the United Kingdom (NAUK).

Dictionary of South African Biography, volumes 1-5.

Maud Wyndham to Lady Leconfield, 23 Aug 1915, PHA, WSRO.

Hugh Wyndham to Lady Leconfield, 21 Jun 1916, PHA, WSRO. Sir Abe Bailey raised a corps of one hundred sharpshooters also for service in France. They left South Africa on April 22, 1916 and arrived too late for the first phases of the Battle of the Somme. Bonar Law to Buxton, 15 Feb 1916, and BB Cubitt to GOC-in-C Eastern Command, 20 May 1916, GG 668, file 9/93/43 War 1914-16: Army, Imperial. Sir Abe Bailey's offer to raise 100 sharpshooters in South Africa for service in France. NASAP. See also Henry Burton to Buxton (Ministers' Minute 966), 5 Jul 1916, DC, Box 756, file DC 1970/9199 Sir Abe Bailey's Sharpshooters, SANDF Documentation Centre. Garson "South Africa and World War 1" op. cit., p. 69.

Hugh Wyndham to Lady Leconfield, 21 July 1916, PHA, WSRO.

Diary, 20-22 Apr 1916, A20 Col HWM Bamford Collection, vol 1, NASAP. Diary, 23 Apr 1916, A20 Col HWM Bamford Collection, vol 1, NASAP. 
War diary, 11 June 1916, WW1 GSWA, box 128, war diary of $1^{\text {st }}$ SA Brigade, SANDF Documentation Centre. See also 'Programme of Battalion Training', June 1916, WW1 Diverse, box 20, SANDF Documentation Centre. See also, Diary, 24 Apr-16 May 1916, A20 Col HWM Bamford Collection, vol 1, NASAP.

Diary, 20-23 May 1916, A20 Col HWM Bamford Collection, vol 1, NASAP.

Diary, 23 May 1916, A20 Col HWM Bamford Collection, vol 1, NASAP.

Diary, 28 May 1916, 30 June 1916, A20 Col HWM Bamford Collection, vol 1, NASAP.

ES Smith. "Die Geneeskundige Diens in die Eerste Wêreldoorlog: Die oorlogsfront in Europa, 1915-1918”. In AE van Jaarsveldt et al. Militêre Geneeskunde in Suid-Afrika, 1913-1983. Pretoria, Military Information Bureau, 1983, 22.

Smith "Die Geneeskundige Diens in die Eerste Wêreldoorlog” op. cit., pp. 2324.

Quartermaster General to Chief Ordnance Officer, 24 Aug 1915, DC, Box 689, file 958/9199 Overseas Contingent. The nominal rolls are on DC 694, file A6/978/9199 General Hospitals for Europe "Overseas Contingent”, SANDF Documentation Centre.

Diary, Thursday, 13 Jul 1916, A164 Sergeant Major Alex J Knox Collection, NASAP.

Diary, 13 Jul 1916, A164 Sergeant Major AJ Knox Collection, NASAP. See also the first sketch in the sketchbook of Captain WL Gordon, BC1096 William Lennox Gordon Collection, C1, UCT.

Diary, Saturday, 15 Jul 1916, A164 Sergeant Major AJ Knox Collection, NASAP.

Diary, Sunday, 16 Jul 1916, A164 Sergeant Major AJ Knox Collection, NASAP.

Smith "Die Geneeskundige Diens in die Eerste Wêreldoorlog ...” op. cit., p. 24.

The Somme war diaries of the siege batteries are in WO 95/542, NAUK and WW1 Diverse, box 20, SANDF Documentation Centre.

'History of the $72^{\text {nd }}$ Siege Battery, R.G.A.', 1-4, WW1 Diverse, box 20, SANDF Documentation Centre.

Ernest Lane to Smuts, 25 Nov 1915, in Hancock and Van der Poel, eds, op. cit., pp. 321-24.

' $73^{\text {rd }}$ Siege Battery, SA Heavy Artillery', WW1 Diverse, box 20, SANDF Documentation Centre.

Diary, 10-13 Jul 1916, A164 Sergeant Major AJ Knox Collection, NASAP. One of its twenty-one MOs, Capt WL Gordon, who has left a wonderfully descriptive diary, enjoyed much leisure time through much of the Somme battles, visiting the madam and mademoiselle at the local chateau, where he dined on steak and fresh vegetables, and ranged the neighbourhood with his sketchbook. See, Gordon to his mother, 16 Aug 1916, UCT: BC1096 Major William Lennox Gordon Collection, B1. His sketchbooks are held by UCT: BC1096 William Lennox Gordon Collection, C1. '73 ${ }^{\text {rd }}$ Siege Battery, SA Heavy Artillery', WW1 Diverse, box 20, SANDF Documentation Centre. 
Tactical news could be passed by word of mouth within the sector. However, for news of a more strategic nature and certainly pertaining to the whole front, soldiers had 'to wait for a home paper to find out what's going on.' NW Nichol to Capt T Purland, 26 Oct 1916, BC477 Purland Family Collection, UCT. Diary, 1 Jul 1916, A20 Col HWM Bamford Collection, vol 1, NASAP. Diary, 1 Jul 1916, A20 Col HWM Bamford Collection, vol 1, NASAP. Diary, 1 Jul 1916, A20 Col HWM Bamford Collection, vol 1, NASAP. Maud Wyndham to Lady Leconfield, 1 Jul 1916, PHA, WSRO.

EB Jamieson to Gordon, 14 Jun 1916, BC1096 Major WL Gordon Collection, B2, UCT.

Humphrey Wyndham to Mary Maxse, 7 Jul 1916, Maxse Papers 455, WSRO. De Burger, 17 Jul 1916.

Hugh Wyndham to Lady Leconfield, 3 Jul 1916 and 7 Jul 1916, PHA, WSRO. Maud Wyndham to Lady Leconfield, 9 Jul 1916, PHA, WSRO. Maud Wyndham to Lady Leconfield, 22 Oct 1916, PHA, WSRO. Maud Wyndham to Lady Leconfield, 15 Jul 1916, PHA, WSRO. Maud Wyndham to Lady Leconfield, 1 Jul 1916, PHA, WSRO. Maud Wyndham to Lady Leconfield, 15 Jul 1916, PHA, WSRO. Smith "Die Geneeskundige Diens in die Eerste Wêreldoorlog” op. cit., pp. 2425.

Diary, Tuesday, 18 Jul 1916, A164 Sergeant Major AJ Knox Collection, NASAP.

Diary, Monday 24 Jul 1916, A164 Sergeant Major AJ Knox Collection, NASAP.

Diary, Monday 24 Jul 1916, A164 Sergeant Major AJ Knox Collection, NASAP.

Diary, Monday 24 Jul 1916, A164 Sergeant Major AJ Knox Collection, NASAP.

Diary, Sunday, 23 Jul 1916, A164 Sergeant Major AJ Knox Collection, NASAP.

Diary, Tuesday, 25 Jul 1916, A164 Sergeant Major AJ Knox Collection, NASAP.

Diary, Tuesday, 25 Jul 1916, A164 Sergeant Major AJ Knox Collection, NASAP.

Buchan op. cit., p. 74.

Gordon to his mother, 16 Aug 1916, BC1096 Major WL Gordon Collection, B1, UCT.

Buxton to Bonar Law, 21 Aug 1916, GG 671, file 9/93/68 Recruiting SA Brigade Overseas, NASAP.

Bonar Law to Buxton, 4 Jul 1916, GG 671, file 9/93/68 Recruiting SA Brigade Overseas, NASAP.

Buxton to Bonar Law, 10 Jul 1916, GG 671, file 9/93/68 Recruiting SA Brigade Overseas, NASAP.

Bonar Law to Buxton, 4 Aug 1916, GG 671, file 9/93/68 Recruiting SA Brigade Overseas, NASAP.

Bourne to Horsfall, 5 Aug 1916, GG 671, file 9/93/68 Recruiting SA Brigade Overseas, NASAP. 
117

Buxton to Botha, 12 Aug 1916, GG 671, file 9/93/68 Recruiting SA Brigade Overseas, NASAP.

As quoted by the Governor General in Buxton to Bonar Law, 21 Aug 1916, GG 671, file 9/93/68 Recruiting SA Brigade Overseas, NASAP.

Buxton to Bonar Law, 21 Aug 1916, GG 671, file 9/93/68 Recruiting SA Brigade Overseas, NASAP. See also Minutes of a meeting of the Imperial War Cabinet, 30 Mar 1917, CAB 23/40, 6(9), NAUK.

GG 668, file 9/93/36 War 1914-16: Army, Imperial. Union Overseas Contingent: protests against failure of Government to make up pay to Defence Force rates, NASAP. See also, Garson "South Africa and World War 1" op. cit. Ministers Minute 1426, 30 Sep 1916, GG 671, file 9/93/68 Recruiting SA Brigade Overseas, NASAP.

Lt Cyril Newton-Thompson to Joyce Nettelfold, 7 Jul 1916, BC643 Joyce Newton-Thompson Collection, B1.43, University of Cape Town Libraries (UCT).

A serious study of the impact of the war on South African society is still lacking. For comparative works see JM Bourne. Britain and the Great War, 1914-1918. London: Hodder and Stoughton, 1991; A Marwick. op. cit.; A Marwick. "The Impact of the First World War on Britain”. Journal of Contemporary History 3/1. 1968; A Marwick. War and Social Change in the Twentieth Century: A comparative study of Britain, France, Germany, Russia and the United States. Basingstoke: Macmillan, 1974; and J Winter. The Experience of World War 1. London: Oxford, 1989.

Maud Wyndham to Lady Leconfield, 8 Dec 1915, PHA, WSRO. Maud Wyndham, incidentally, was descended from the very core of those families that had governed Britain during the eighteenth and nineteenth centuries and her ancestors include both Chatham and Marlborough.

Maud Wyndham to Lady Leconfield, 8 Dec 1915, PHA, WSRO.

Lt Cyril Newton-Thompson to Joyce Nettelfold, 21 Jul 1916, BC643 Joyce Newton-Thompson Collection, B1.53, UCT.

Lt Cyril Newton-Thompson to Joyce Nettelfold, 21 Jul 1916, BC643 Joyce Newton-Thompson Collection, B1.53, UCT.

Emily Hobhouse to Smuts, 8 Aug 1914, in Hancock and Van der Poel, eds., op. cit., p. 186. This idea still has currency in South Africa. See, for example, Greg Mills. "Cannon fodder for man's first mechanised mass murder". The Sunday Independent, 13 Feb 2005, p. 17: 'They were brave, but the war itself was a costly folly and the political leaders who caused it were callous and inept.'

NW Nichol to Capt T Purland, 1 Aug 1917, BC477 Purland Family Collection, UCT.

The repercussions of industrialized warfare have been addressed by AR Millett and W Murray. Military Effectiveness, vol 1: The First World War. Boston: Unwin Hyman, 1988; T Travers. The Killing Ground: The British Army, the Western Front, and the Emergence of Modern Warfare, 1900-1918. London: Allen and Unwin, 1987 and How the War Was Won: Command and Technology in the British Army on the Western Front, 1917-1918. London: Routledge, 1992; A Ashworth. Trench Warfare, 1914-1918: The Live and Let Live System. London: Holmes, 1980; and others. 
Smuts to Wolstenholme, 29 Nov 1915, in Hancock and van der Poel, eds., op. cit., pp. 324-25.

See Merriman's speech quoted in "Union's Roll of Honour. Deathless Deeds at Delville Wood. Musical Memorial Service in the City Hall. Mr Merriman on South Africa’s Heritage”. Cape Times, 19 Jul 1917, p. 6.

Circular from Maj Gen W Furse $\left(9^{\text {th }}\right.$ Scottish Division) to brigade commanders, 21 Jul 1916, WO1DA, box 5, war diary South African Infantry Brigade Headquarters, July 1916, SANDF Documentation Centre.

Brig Gen HT Lukin to Maj Gen W Furse, 3 Aug 1916, WO1DA, box 5, war diary South African Infantry Brigade Headquarters, July 1916, SANDF Documentation Centre. This has been quoted at length in Uys op. cit. In 1921 "UDF Infantry Training, Part I (Drill) and Part II (Field Operations"; "UDF Field Artillery Training”; "UDF Musketry Regulations"; a revision of "Mounted Riflemen Training”; "Tactical Notes for Officers"; and "Notes on Field Sanitation" were in the process of preparation.

JAI Agar-Hamilton. "The Union of South Africa War Histories". In Robin Higham, ed., Official Histories; Essays and Bibliographies from around the World. Westport: Greenwood, 1970. 443.

Collyer began his military career with the Cape Mounted Riflemen and saw action in the Second Anglo-Boer War as well as the two African campaigns of the First World War. He retired as Chief of the General Staff in 1920, when he embarked upon his histories of the South West and East African campaigns, which received official sanction in 1936. The pointing out of 'mistakes' was the most important of several motives that prompted the writing of these works. See I van der Waag. "Contested histories: official history and the South African military in the $20^{\text {th }}$ century”. In Jeffrey Grey, ed., The Last Word? Essays on Official History in the United States and British Commonwealth. Westport, Connecticut and London: Praeger, 2003. 27-52.

Preface in JJ Collyer. The South Africans with General Smuts in German East Africa, 1916. Pretoria: Government Printer, 1939. See also D. Visser. "British Influence on Military Training and Education in South Africa: The Case of the South African Military Academy and its Predecessors". South African Historical Journal 46. 2002. pp. 63-82.

JSM Simpson. South Africa Fights. London: Hodder and Stoughton, 1941. 91.

'So far as the enemy troops were concerned, aerial action did little damage and produced trifling information.' Collyer op. cit., p. 87.

Collyer op. cit., pp. 266-277 as well as Oswald Pirow. James Barry Munnik Hertzog. Cape Town: Howard Timmins, 1957. 219. and PE von LettowVorbeck. My Reminiscences of East Africa. London: Hurst, 1920. 50.

See, for example, Fremantle to Hertzog, 12 Nov 1923, A608 HES Fremantle Collection, vol 14, NASAC.

I van der Waag. "South Africa and the War in Asia Minor, 1921-1923". Militaria 24/1. 1994. pp. 9-19.

"Dr Malan en die Dardanelle”. Volkstem, 2 Sep 1922.

"Geen man en geen pennie; Ons leier oor die wereld-krises". Ons Vaderland, 22 Sep 1922.

Buchan op. cit., p. 260. 